\title{
Women and Islamic Movements
}

\author{
Eva F. Nisa
}

\section{Introduction}

Muslim women have long been the backbone of the development of Islam, including Islamic thoughts, practices, and movements. This chapter focuses on the complex trajectory of women's movement and women's activism in various Islamic movements, including their struggle for women's rights. Despite their extensive contributions, Muslim women's roles in the development of Islamic thoughts, practices, and movements are often overlooked. Establishing female religious authority, for example, has been an issue in many Muslim countries since the advent of Islam and throughout its development. Meanwhile those who have spoken on behalf of Islam, from its earliest days, were not only men but also women (see Krämer and Schmidtke 2006; Künkler and Nisa 2018). Both men and women have shared their thoughts and expertise to their Muslim fellows, becoming the sources of guidance for Muslims throughout Islamic history. In addition, Muslim women have been active in forming their own Muslim organisations and have become important agents in diverse Islamic movements ranging from ultra conservative to moderate and progressive movements. However, studies on religious authorities often mention Muslim women and their movements only as an appendix of men's religious authorities, though theoretically women and men hold the same responsibility to understand and transmit religious knowledge. ${ }^{1}$

This chapter analyses Muslim women and their religious activism, both as individuals or part of diverse Islamic and Islamist movements. It cannot not be all-inclusive because of the complexity and immensely diverse affiliations and movements that Muslim women have been a part of to date. It also touches on but does not intend to problematise historical debates of women's presence and their roles in the early community. Rather, this chapter will briefly

1 Many Qurānic verses and hadīth (reports or the words and deeds ascribed to the Prophet Muhammad) emphasise this duty of seeking and transmitting knowledge an act of worship, for example, Qurān 58:11 "God will exalt, by [many] degrees those of you who have attained to faith and, [above all], such as have been vouchsafed [true] knowledge: for God is fully aware of all that you do." 
sketch some common traditional narratives of early Muslim women to serve as a bridge to the main discussion of women and Islamic movements. In this section both moderate and conservative movements will be looked at to examine the roles of women within, and the impact of Islamic feminist consciousness. Part of this discussion is the assessment of scholarship by women academics on this topic which forms a central aspect of the methodology and analysis of Muslim women in the modern practice of Islam.

\section{$2 \quad$ Women of the Prophet Muhammad's Circle}

Muslim women, from the most conservative to the most liberal, place the women of the Prophet Muhammad's household, especially ummahāt al-Mu'minin (mothers of the believers), as role models and main references for the faith (see Stowasser 1997: 115). In analysing Muslim women and Islamic movements, therefore, this chapter necessarily commences with a brief overview of the women within the Prophet Muhammad's circle and other pious female companions. Among the wives of the Prophet Muhammad-some say eleven and others thirteen - three wives in particular are often mentioned as leading role models for Muslim women: Khadija bint Khuwaylid (556-620), 'Ā'isha bint Abī Bakr (604-678), and Umm Salama (594-68o). In addition to the ummahāt al-Mu'minīn, one daughter of the Prophet Muhammad Fāțima al-Zahrā' is an important figure for many Muslims. The Qur'ān also mentions other women, such as the Virgin Mary (or Maryam), the mother of Jesus (or 'Isā) and Āsiyā bint Muzāhim, the wife of the Pharaoh and adoptive mother of Moses (Abboud 2014).

It is especially important to look to the life of 'A'isha, the Prophet Muhammad's favourite wife, who was the daughter of his close companion and first caliph (al-Khulafǟ al-Rāshidūn), Abū Bakr al-Ṣiddīq (573-634) (see also Abbott 1942). There is some contestation about 'Ā'isha's age at the time of her marriage to the Prophet Muhammad. Some narrations say that she was six years old when the marriage contract was concluded, but the consummation took place when she reached puberty. Others mention the marriage was consummated when she was nine. For example, one of the collections of hadith, (pl. ahädīth) Șahịh al-Bukhārī, in the Book of Marriage, recorded "that the Prophet married her when she was six years old and he consummated his marriage when she was nine years old" (al-Bukhārī n.d.). Some scholars contend that the age signifies that she had reached physical maturity according to that time in history (Brown 2014: 142-3; Barlas 2002: 125-126). 
Those who are interested in understanding 'A'isha often problematise her age at marriage, the conflict with 'Alī, and the infamous hadith al-ifk (the incident of the lie) or accusation of adultery. Hadith al-ifk refers to rumours that 'Á'isha was unfaithful and had committed adultery with Șafwān ibn Mu'ațtal. One of the most infamous examples is a controversial fictional novel by Sherry Jones, The Jewel of Medina (2008). This fictional book was inspired by Islamic history but has twists to suit the author's interests (see Larsson 2015: 104), depicting 'Â'isha negatively including emphasising her special relationship with Ṣafwān (Jones 2008: 178-179). Sunnī Muslims, however, believe that 'Ā'isha was innocent and falsely accused.

The Prophet's marriage to 'Â'isha is important for Sunnī Muslims as it has often been mentioned as one of the signs that Muhammad desired Abū Bakr as his successor, rather than his cousin 'Alī ibn 'Abī Ṭālib, as Shīì Muslims believe (see Thurlkill 2010: 91). Her status as the wife of Muhammad in addition to her intelligence have positioned 'Â'isha as one of the main references for the Muslim community, especially Sunnī Muslims. 'Ā'isha's authority originated from the fact that she was present during the lifetime of the Prophet and witnessed the life of the Prophet, the living role model of ideal persona for all Muslims. During her lifetime, 'Â'isha was one of the principal transmitters of hadīth (see Stowasser 1997).

'Á'isha took an active role in political affairs. She was involved in the first civil war among Muslims after Muhammad's death. The opponents of 'Ā'isha's political activities have criticised her involvement in the Battle of the Camel in 656 , a battle named after the camel that 'A'isha rode during the battle between her and 'Alī. Progressive Muslim scholars, activist women, and Islamic feminists, on the other hand, emphasise 'Â'isha's venture into the political arena as evidence of women's full participation in early Muslim society. As Leila Ahmed contends, "her venture is itself a sign of the community's acceptance of women as capable of leadership and is important in that it even occurred" (1992: 74).

Shīī Muslims have perceived the battle between 'Ā'isha and 'Alī differently to Sunnī Muslims. Many Shīìs consider her as an opponent of Shīì's first imām (a leader of Muslim community) and the fourth caliph, Imām 'Alī. They often contrast 'Â'isha's position to other important figures from the Prophet's household, especially his daughter Fāțima. Mary Thurlkill notes that Shīites have argued that Fāțima's importance transcends that of her mother, Khadija, Mary, the mother of Jesus, and 'Â'isha (2010: 19). Within Shīīi hagiographical tradition, Fāțima is depicted as a woman with theological authority, prophetic insight and the mother of Shīì imāmate (umm al-ä'imma) (Thurlkill 2010; Ruffle 2020). She has continuously become the source of emulation for 
contemporary Shīīi women, including Shīī Islamic feminists (Fazaeli 2017: 61). Besides Fāțima, Shīīs also often juxtapose 'Ā'isha with another wife of the Prophet Muhammad, Umm Salama (Spellberg 1991: 51). However, the records suggest Umm Salama did not enjoy as much influence on Islam as did 'Â'isha: "compilers have enumerated between 1,500 and 2,400 hadith for which 'Aisha is the first authority. Umm Salama, though a distant second, contributed between 175 and 375 reports" (Sayeed 2015: 25).

The position of 'Â'isha against other women within the Prophet Muhammad's circle signifies that the early contestation between Sunnī and Shī'a did not only involve male successors of the Prophet Muhammad, but also debates regarding the leading female religious authority for the Muslim community. Among Shīìi, including contemporary Shīī activist women, Fāțima's daughter Zaynab bint 'Alī has also become a role model of ideal womanhood. Lara Deeb records in the context of 'Āshürā', the annual commemoration marking the martyrdom of Imām Husayn, that "lay women focus on Zaynab as the dominant female figure of Ashura, emphasizing her presence at the battle and her role as the community's leader following Husayn's martyrdom" (2006: 32).

\subsection{Aftermath of the Death of the Prophet}

In the aftermath of the death of the Prophet Muhammad and women within his circles, the central orthodoxy of Islam became increasingly patriarchal. This pattern can be seen in various Islamic traditions. Within Sūfì tradition, for example, Șūfì biographies and hagiographical literature often mention Șūfì women as spiritual guides, saints, and muhibbāt (lovers), especially in the ninth to eleventh centuries, before the institutionalisation and development of țuruq (Ṣufī orders) in the twelfth century (Krokus and Catharina 2020). The most notable of them was Rābi'a al-'Adawiyya (d. 8o1). Later, patriarchal traditions linked to social propriety became the main opposition to the leadership of Şūfĩ women and their ability to become pirs (spiritual leaders).

One major concern within the Muslim community has been the way classical literature within Islamic literary genres, including within the development of the Qur'ānic exegesis (tafsir), emphasises gender differences between women and men. The premodern era gave birth to Muslim theologians and jurists who interpreted the Qurân through patriarchal perspectives. Indeed, during that period Qurānic exegesis can be regarded as having a significantly male prerogative. The socio-political contexts of the later era within the Islamic world, embedded in patriarchal societies, have influenced the products of Qurānic exegesis and the emergence of misogynistic hadìth. Fatima Mernissi (1998), a Moroccan feminist sociologist, in her criticism of some companions 
of the Prophet and male Muslim scholars, like Abū Hurayra (d. 678), al-Bukhārī (810-870), and their misogynistic hadith narrations and collections, emphasises how these early Muslim scholars misinterpreted, and sometimes incompletely presented, Islamic sources on the position of women. A hadith from al-Bukhārìs collection mentions "Three things bring bad luck: house, women, and horse," as Imām al-Zarkashī (745-794) records:

They told 'A'isha that Abu Hurayra was asserting that the Messenger of God said: 'Three things bring bad luck: house, woman, and horse.' 'A'isha responded: 'Abu Hurayra learned his lessons very badly. He came into our house when the Prophet was in the middle of a sentence. He only heard the end of it. What the Prophet said was: "May God refute the Jews; they say three things bring bad luck: house, woman, and horse".

quoted in MERNISSI 1998: 123

Aisha Geissinger (2015) in her work mentions how after the era of the Prophet's wives, Muslims witnessed a decrease of women in the domain of exegetical roles. Karen Bauer (2015) also argues that premodern exegetical works pertaining to certain issues on gender and hierarchy have influenced modern interpretations of the Qur'ān and the later exegetes. Therefore, modern conservative readings of the Qurān maintain the views of medieval exegetes by emphasising that women are equal but different, due to their 'natural' qualities. The most common pattern within early exegetical work was that male exegetes influenced by patriarchal forces dominated the discussion of women.

The Qurānic exegeses by women can be found in the late nineteenth and early twentieth centuries. One of the most important figures in this context is 'Â'isha 'Abd al-Raḥmān (1913-1998), the wife of renowned Egyptian scholar Amīn al-Khūlī (1895-1966), known by her pseudonym Bint al-Shāṭi' (Daughter of the Shore). Bint al-Shātị was an exceptional scholar in the Arab world who published more than sixty books, including those on Qur'ānic exegesis (see Boulatta 1974). As one of the first Muslim women to focus her work on Quraanic exegesis, she has become an inspiration for many Muslims, including Islamic feminists (Roded 2006: 51). During her lifetime she never declared herself a feminist; indeed, her depictions of the wives within the prophet's household are considered as problematic (see al-Shati 1961). Ruth Roded argues that when Bint al-Shāți' portrayed the Prophet's wives, "there are stereotypical depictions of women's petty jealousy that would hardly be considered feminist, the author raises a common feminist claim - that the perception of women's lives by male authors will always be lacking because they are 'ignorant of 
female instinct"' (2006: 52). However, Roded contends that her lecture titled al-Mafhüm al-Islämy li Tahrïr al-Mar'ah published in 1967 was often considered proof that Bint al-Shāți' was, in fact, a forerunner of Islamic feminism (2006).

The discussion of women and Islamic movements need not to neglect the nonArab premodern era. The main inspirations for later Muslim women activists and their Muslim women's organisations, were not only women of the Prophet Muhammad's household but also non-Arab premodern era female figures, including female rulers in the premodern era (see Reid 1988: 640; Andaya 2006). In South Asia, Sultana Raziya of the Delhi Sultanate (c. 1236-1240), as the only female ruler of the premodern age in the Indian subcontinent, has often been mentioned as a role model (Brijbhushan 1990). Following this, the role of women in the early Mughal Empire was an important inspiration for later women activists (Lal 2005). Southeast Asia witnessed the presence of the first Muslim queen or sultana, Sultana Taj al-Alam Safiyat al-Din Syah, who reigned between 1641 and 1675 . Taj al-Alam has been described as "a devout patron of Islam who only spoke to European men from behind a curtain" (Andaya 2006: 167). Later in the nineteenth century, Tjoet Nja Dien (c. 1848-1908) and Tjoet Nja Meuthia (1870-1910) were also known as Muslim female warriors and national heroines in the archipelago who fought against the Dutch and became role models for later generations (see Clavé 2020: 109).

Mernissi (1993) has listed fifteen queens across the Islamic empires and how their roles broke the chains of patriarchal norms which suggest that women's access to power can lead to chaos. Mernissi recorded that women were often excluded from being appointed for religious authority, however in the domain of political authority history demonstrates that they were present, such as sultana within the Mamluks in Egypt, and malika (queen) within Yemeni dynasties. The presence of these female rulers, however, has not had a significant effect in reforming the prevalent discourses pertaining to the patriarchal reading of religious texts.

Further across Muslim-majority countries, the position of women in Islam was one of the main aspects attacked by colonial powers. Thus, issues pertaining to Muslim women's rights and their status were also part of an imperialist agenda. In many Muslim majority countries, the anti-colonial period was not an easy time for Muslim women who fought for women's rights because they were under pressure to conform to anti-colonialist and nationalist agendas. As Ziba Mir-Hosseini notes, "for anti-colonialists and most nationalists, 
feminism - that is, advocacy of women's rights — was a colonialist project that had to be resisted" (2006: 639). The complicated situation faced by Muslim women during that period was depicted in Ahmed's expression as a dilemmatic choice "between betrayal and betrayal" (1984) referring to the way early feminists were in limbo between being loyal to their Muslim identity so that they were not accused of cultural betrayal and betrayal to their new gender awareness. As Ahmed puts it, "it is precisely the matter of cultural loyalty that, currently skilfully manipulated in militantly Islamic societies, is behind such bizarre phenomena as women marching and protesting, in the name of cultural authenticity, in support of the revoking of their own rights" (1984: 121-2).

\section{4}

\section{Women's Rights Consciousness and Islamic Feminism}

The patriarchal reading of religious texts during the premodern era has had a significant influence on Muslim communities in the modern period, particularly relating to the status of women in Islam. This includes domestic seclusion, gender segregation, and educational access. Muslim women have recognised the problems pertaining to embedded patriarchal readings of religious texts, but it is also noteworthy that men have been important figures in struggle for female emancipation. Mernissi praises Imām al-Zarkashī, for example, who acknowledged 'Â'isha's contribution to the development of hadith (1998: 124).

The discussion of Muslim women and their movement for rights cannot be separated from the role of modernist movements in different parts of the Islamic world, from the Ottoman Tanzimat's (1839-1876) efforts to address gender inequalities, which can be se seen in the first establishment of secondary school for girls in 1858, to the presence of modernists in the Arab world in the late nineteenth century, such as Rifā'ah Rāfi' al-Ṭahțāwī (18o1-1873) and his disciple, Muhammad 'Abduh (1849-1905). 'Abduh focused on defending women's rights and their status, especially in the domain of providing them access to education and preventing arbitrary polygamy. 'Abduh was very strict about the practice of polygamy and called for polygamy abolition (see 'Abduh n.d.: 117-118). 'Abduh's disciple, Qāsim Amīn (1863-19o8) was also one of the most important writers calling for women's issues in Egypt. The later generation of male progressive thinkers have also contributed to the discussion of gender equality, such as Fazlur Rahman (1919-1988), Mohammad Arkoun (1928-2010), Nasr Hamid Abu Zayd (1943-2010), Muhammad Shahrour (19382019), Mohammad Mojtahed Shabestari (b. 1936), Abdulkarim Soroush (b. 1945), Abdullahi Ahmed An-Na'im (b. 1946), and Khaled Abou el-Fadl (b. 1963) (see Mir-Hosseini 2016: 70). 
Along with this, the rise of women's rights consciousness or "feminist consciousness," to borrow Margot Badran's phrase, can be seen in many Muslim societies from the late nineteenth century. Egypt is especially important in the discussion of women's activists, feminists and their movements. Many scholars, including Badran, have argued, that "the feminist movement in Egypt, in many ways, was prototypical of secular feminist activism elsewhere in the Muslim world in the first half of the twentieth century" (2019). To begin with, Malak Hiifnī Nāṣif (1886-1918), the first woman in Egypt to become a teacher, is known as one of the early feminist writers in the country (Yousef 2011: 70). Nāșif experienced gender discrimination firsthand. Receiving a diploma in 1900, she was banned from teaching after her marriage. This condition, however, did not stop her activities. She was active in contributing articles in al-Jarìdah - a liberal/nationalist paper initiated by Aḥmad Luṭ̂i al-Sayyid, the founder of the Hizb al-Umma (Umma Party) (Yousef 2011: 73), writing under her pen name Bāhithah al-Bādiyah (The Searcher of the Desert). In 1911, Nāṣif listed feminist demands to the Muslim nationalist congress in Heliopolis which was conveyed without her presence, because at the time women in Egypt were not permitted to appear in public in front of men. Some of the points mentioned in the demands related to women's freedom to participate in congregational prayer in mosques, females' access to education and work, reforms of the Muslim Personal status code, as well as broader socio-religious reforms (Yousef 2011: 71). In 1914, Nāșif and other women, including another feminist leader Hudā Sha'rāwī, founded the Women's Refinement Union (al-Ittiḥād al-Nisā̄ī al-Tahdhībī) and the Ladies Literary Improvement (Jam'ìyat al-Raqy al-Adabīyah li-al-Sayyidāt al-Mișrīyat). Nāșif died of Spanish influenza when she was thirty-two years old. Her work was then continued by Hudā Sha'rāwī.

Hudā Sha'rāwī (1879-1947) was known as one of Egypt's feminist leaders. Continuing Nāṣif's struggle, Hudā formed the first explicitly feminist organisation in Egypt, the Egyptian Feminist Union in 1923 (Badran 1995: 37). Active in the Egyptian public sphere during the time leading to the nationalist Revolution, Sha'rāwī was also involved in the movement for Egypt's nationalist Revolution from 1919 to 1922 (see Kahf 1998: 53). Before her death in 1947, Sharāwī was appointed as the president of the Arab Feminist Union founded in 1945. Following Sha' rāwī, many Muslim women in Egypt and elsewhere also established women's movements. In 1948, for example, Durīyya Shafĩ or Doria Shafik (1908-1975) founded Bint al-Nìl (Daughter of the Nile), focusing on women's political participation in Egypt and abolishing illiteracy (Blaydes and El Tarouty 2009: 366). Her staunch struggle for political equality and womens' right to vote resulted in the issuance of a new Constitution in 1956 that granted women this right (Blaydes and El Tarouty 2009: 366). 
Continuing the struggles of early Muslim feminists, in the late twentieth and early twenty-first centuries, feminists began focusing their agenda on women's bodies and sexuality. One of the most famous feminists and women activists working on women's bodies and sexuality is Nawāl al-Sa'dāwī or El Saadawi who in 1982 founded the Arab Womens' Solidarity Association (Saadawi 1997: 24). al-Sa'dāwī contends:

We Arab and Muslim Women know that our authentic identity is based on unveiling our minds and not on veiling our faces. We are human beings and not just bodies to be covered (under religious slogans) or to be naked (for consumerism and Western commercial goods). We know that veiling of women is the other side of the coin of nakedness or displaying the body. Both consider women as sex objects (1997: 97).

Mernissi, in her book Beyond the Veil, also discusses women's bodies and sexuality, and their relationship with the concept of fitna (disorder or chaos). She explores the influence of this concept on women who have been seen as dangerous creatures who produce fitna through sexual disorders, thus, need to be controlled through practices such as veiling and seclusion $(1987: 31)$.

\subsection{Islamic Feminism}

Islamic feminism emerged as a discourse rather than a social movement in the last quarter of the twentieth century, particularly from the 1980 s and $1990 \mathrm{os}$ when it became especially noticeable (Badran 2002). Triggers that have given impetus to the presence of Islamic feminism include the spread of conservative movements, especially Islamist movements, and disappointment with secular authoritarianism (Badran 2005: 9; Schröter 2017: 116). Badran argues:

The basic argument of Islamic feminism is that the Qurann affirms the principle of quality of all human beings but that the practice of equality of women and men (and other categories of people) has been impeded or subverted by patriarchal ideas (ideology) and practices. Islamic jurisprudence, figh, consolidated in its classical form in the gth century, was itself heavily saturated with the patriarchal thinking and behaviours of the day (2002).

Thus, Islamic feminism can be regarded as a new approach to the genderegalitarian interpretation of Islamic religious texts, usually known as a discourse focusing on women-sensitive rereading of religious sources, especially the Qur'ān. 
The product of patriarchal readings of religious texts, as Badran mentioned, has strengthened those who argue that Islam is the signature cause of women's troubles. Bronwyn Winter, for example, who rejects progressive readings of Islam, contends "all monotheistic religious texts as oppressive to women" (Winter 2001: 12). She calls those who embrace progressive rereading of the texts-which can be seen as a latter product of progressive Muslim thinkers as- "apologists." She argues, "Scholars following the apologist framework claim that Islam made things better for women, but the fundamentalists misinterpret it-which corresponds roughly to the 'multiculturalist' discourseor that the Quran is open to interpretation, and feminist interpretations can be made - which corresponds roughly to the "pluralist discourse" (2001: 13).

The spirit of Islamic feminism in the 1980s can be seen in the development of Muslim feminist solidarity networks and organisations. One of the earliest is Women Living Under Muslim Laws (WLUML) which was founded in 1984 by women from Algeria, Morocco, Sudan, Iran, Mauritius, Tanzania, Bangladesh, and Pakistan. In the context of Islamic feminism, women's activists, including a few men, in Iran had been considered as important agents of this new wave. These activists and thinkers published their thoughts on gender justice in Islam in Zanan, a journal founded in 1992 by Shahla Sherkat. Indeed, Zanan was an important publication which had initiated the use of Islamic feminism. It is noteworthy that the main writers of Zanan offering gender justice perspective between 1992 and 2008 were men (Fazaeli 2017: 59). Sherkat and her colleagues used Zanan as their platform for Islamic readings of gender equality and justice. This phenomenon can be seen in other countries, such as Sisters in Islam, a Malaysian based nongovernmental organisation mainly of Malay Muslim professional women, founded in Malaysia in the late 1980s and formally registered in 1993 (Basarudin 2016: 4, 12), and Musawah (Equality), a "Global Movement for Equality and Justice in the Muslim Family" founded in 2007 and was officially launched in Kuala Lumpur in 2009.

Some most often mentioned figures in this context who have focused their attention on rereading the Qurān are Amina Wadud, Rifaat Hasan, Fatima Naseer, Aziza al-Hibri and Shaheen Sardar Ali. Wadud, an African-American theologian, has been known as a main figure in the rereading of the Qurān (see Badran 2001: 50; see Wadud 2006). Two seminal treatises considered to be foundational texts of Islamic feminism are Wadud's Qur'ān and Woman: Rereading the Sacred Text from a Woman's Perspective and Pakistani-American scholar Barlas' 'Believing Women': Unreading Patriarchal Interpretations of the Qur'ān.

Although this movement has inspired many other Muslim women's movements across the globe, it is noteworthy that the term "Islamic feminism" has 
been highly contested and even explicitly rejected by some Muslim women activists and scholars. Asma Barlas, for example, has been critical about being labelled as feminist due to its ethnocentric undertones. Barlas responded to Badran's "Islamic feminism" in her "Four Stages of Denial or my On-again, Off-again, Affair with Feminism" (2008: 16). Barlas contends, "So, when we call something Islamic feminism we close off the possibility of seeing it as anything else and it is this closure that I find problematic. When we ignore how people choose to name themselves, their work, and their struggles, we necessarily do some epistemic violence to them" (2008: 21-22).

Haideh Moghissi is another one of the scholars who has been critical of the Islamic feminist project (see also Schröter 2017: 128). In her work she asks a question, "Islamic feminism' is connected with the question of the compatibility of feminism with Islamic teaching and scripture, and the social and legal frameworks which have evolved in Islamic societies. How could a religion which is based on gender hierarchy be adopted as the framework for struggle for gender democracy and women's equality with men?" (1999: 126). Further, she argues:

Feminism's core idea is that women and men are biologically different, but this difference should not be translated into an unequal valuation of women's and men's experience; biology should not lead to differences in legal status, the privileging of one over the other. This idea is diametrically opposed to the basic principles of Islam ... the Qurān makes men 'the managers (Qawwamoun) of the affairs of women', because 'God has made the one to excel over the other', assigning men the task of admonishing women when they fear they may be rebellious (1999: 140).

Therefore, she believes that, gender equality is alien to Islam 'essence' and the basic principles of Islam as mentioned in the texts. The exponents of Islamic feminism undoubtedly criticise Moghissi's position. Ahmad, for example, argues, "Islam has no essence; hence a non-patriarchal reading of Islam is plausible. It is my contention that it is not the Qurān per se, which legitimates gender hierarchy, but the person making interpretation thereof and the context in which it is done" (2008: 551$)$.

It is important to note despite the presence of scholars criticising Islamic feminism, the discourse, movement, and its spirit of gender-just rereading of Islamic texts have spread across the world. Many Muslim women who lack understanding and knowledge of gender just interpretations of the Qurān and other religious texts, however, are still unfamiliar with their agenda (Nisa 2019: 441). In addition, within the Muslim-majority countries, the widely spread 
assumption is that women's activism, in particular feminists including Islamic feminists, are promoting foreign Western ideas which are at odds with Islamic values. Therefore, although it is regarded as a transnational movement, this progressive movement has not gained significant appeal for Muslim women. The following section will focus on Islamic movements and their women's wings to cater to their female constituents.

\section{5}

\section{Muslim Women and Moderate Movements}

Women belonging to diverse Islamic movements have contributed greatly in the development of democracy and better gender relations (see Robinson 2008 regarding Indonesia). Robinson provides a crucial study on the important position of women activists as agents of reform and leading players in the fall of the authoritarian New Order regime in May 1998, a regime of hegemonic masculinity. Unfortunately, the end of the New Order was not the end of women's domination and inferiority. Robinson argues, "Politicized Islam has emerged as an important force in the democratic atmosphere of the Reform period. Islamic voices that had been subdued under the New Order have found a public stage" (2008: 165).

Issues dealt by women's activists of Islamic movements mirror those belonging to Islamic feminism or secular feminism, such as access to and development of women's education, polygamy, forced marriages and child brides. Different contexts, however, have different foci due to the specific and localised nature of their problems. Therefore, some of the issues confronted by women of the Middle East and North Africa, like the removal of the face-veil, are not issues faced by Muslim women in Asia where face-covering is not the norm. Another example can be seen from the system of purdah or female seclusion which is observed especially within the Indian subcontinent (Minaut and Papanek 1982). In addition, the characteristics of diverse expressions of Islam in different contexts have also coloured women's activism. For example, the development of Șüfism in South Asia has led to the high presence of women's participation in devotional activities at Sūfi shrines, which are central within Șüfi tradition (Abbas 2002). Indeed, the presence of women holding authority as pirs has increased in the subcontinent (Pemberton 2006).

Women within moderate circles in Muslim majority countries have successfully established their women's wings and, in certain contexts, demonstrated their independence in responding to issues pertaining to women. They do not always echo the views of men within the organisations. The presence of 
women's wings within moderate mainstream Muslim organisations, can be seen in the world's largest Muslim majority country, Indonesia. Indonesia has two of the largest Muslim mass organisations, Nahdlatul Ulama (NU) founded in 1926, and Muhammadiyah established in 1912. Both organisations have female wings ranging from female student associations to adult women associations.

Within the organisational structure of NU, women's organisations are part of its autonomous bodies. Muslimat NU is known as a NU women's organisation, Fatayat as a NU young women's organisation, and IPPNU (Ikatan Pelajar Putri Nahdlatul Ulama or NU School Girls Organisation) as a NU female students' association (Bush 2009: 15). Each of these female organisations has its own specialities and agenda which might overlap or differ from one another. Despite being widely known as a moderate Islamic organisation, $\mathrm{NU}$ is still rooted in patriarchal norms, which is evident in the position of women within the highest organisational structure of NU, PBNU (Pengurus Besar Nahdlatul Ulama, Executive Board of NU). Muslim women within NU have continuously voiced their concerns pertaining to the position of women in the highest level of NU's leadership structure, PBNU. They have demanded revision to NU's constitution to allow women representatives at the PBNU level (Bush 2009: 159). Women activists within NU organisations, especially Fatayat NU, have long been regarded as progressive women (Arnez 2010: 81). Belonging to an Islamic movement, Fatayat has been inspired by and actively collaborated with other progressive scholars, including Islamic feminists, such as Amina Wadud, Ziba Mir-Hosseini, Asma Barlas, Margot Badran, Amina Rasul, and Vivien Wie, (Nadjib 2019). Fatayat, according to Schröter, "have taken on leading roles in the further development and localization of ideas taken from Islamic feminism" (2017: 126).

Muhammadiyah, usually known as a reformist and modernist Islamic organisation in Indonesia, also has affiliated women's organisations. The women's section of Muhammadiyah is called Aisyiyah and was initially led by the wife of founder, Nyai Ahmad Dahlan. Aisyiyah can be regarded as Muhammadiyah's version of Muslimat NU. The equivalent to Fatayat is Nasyiatul Aisyiyah. The term 'Aisyiyah' was intentionally adopted from 'Ā'isha, the Prophet Muhammad's wife. As mentioned above, the roles of the wives and women within the family of the Prophet Muhammad have continuously been the main inspiration for later women's activism and their movements. Similar to Fatayat, the agenda of Nasyiatul Aisyiyah is also more progressive than Aisyiyah. Nasyiatul Aisyiyah has experienced moments when it has opposed Aisyiyah, which has been more conservative when engaging 
with gender issues. Syamsiyatun records, "Some Aisyiyah women even tried to block the spread of the gender 'virus' among Aisyiyah by not allowing Nasyiah women to talk about gender issues within Aisyiyah's pengajian [Islamic study group]" (2007: 87).

The dynamics within these women's wings of Islamic movements come from the brand of moderate (wasatiyya) Islam in their given country, demonstrating that different positions pertaining to various women's issues can be seen even within one organisation (see also Van Doorn-Harder 20o6). The following section will focus on women and their organisations within the circle of more conservative movements, especially Islamist movements.

Muslim Women and Conservative Movements

Earlier in the section on Islamic feminism, this chapter mentions that the discourse of Islamic feminism initially emerged as part of the response of activists and thinkers to the rise of conservative movements, including Salafism and diverse Islamist movements. Notably, some began attaching themselves to diverse Islamist movements at the same time as when other Muslim women were attracted to feminist activism. Mounira Charrad, in her study on gender in the Middle East, argues that due to better access to education and the end of colonialism in many Muslim countries in the 198os, Muslim women's movements could be seen flourishing (2011: 425) including those of Islamist movements. Echoing other scholarly positions, such as the position of Ahmed mentioned above, Charrad argues, "Although some may come close to it, most groups differentiate themselves from Western feminism, which has been perceived in the region as a legacy of colonialism and Western hegemony, having little relevance to the Middle East" (2011: 425). This section focuses on the most current scholarly concerns on the growing presence of women becoming part of diverse conservative and Islamist movements and their parties.

\subsection{Salafism}

Salafism is the oldest root of many conservative and revivalist movements, including diverse Islamist movements that have also been inspired by some Salafi ideologies in their understandings of Islam. It is noteworthy that throughout its development, there have been many groups identifying as belonging to Salafism, especially traditionalist Salafism. Scholars (Wiktorowicz 2006; Meijer 2009) often mention the three major factions: purist, political, and jihadi. The position of women within diverse Salafi movements and groups can be seen not only within Muslim majority countries (Nisa 2012, 2013, 2014; Inge 2016; 
Tønnessen 2016; Kolman 2017). My work focuses on Salafi women within purist and political Salafism - to borrow Wiktorowicz's classification-in Indonesia. I analyse the agency of young Salafi women in Indonesia living under specific strict Salafi understandings of Islam, including the injunction that women should ideally wear face-veils (Ind. cadar) to guard their morality (2012: 367 ).

The struggle of these Salafi women to defend their conservative understandings of Islam can be seen in Muslim majority and Western countries. Liv Tønnessen (2016), for example, concentrates on the political agency of Salafi women in Sudan in their fight against the state's understanding of gender mixing (in Tunisia see Kolman 2017). Anabel Inge (2016) analyses the life of young, British Salafi women and their process of conversion, as well as the constraints they face when negotiating between their Salafi identity and Western lifestyle (on Moroccan-Dutch Salafi women, see de Koning 2009). These scholarly works emphasise the important role played by Salafi women within diverse Salafi groups not only by supporting the strict conservative Salafi understandings of women's positions in Islam, but also in strengthening their movements by inviting others to uphold the same strict understandings of Islam.

\subsection{Muslim Brotherhood}

The most famous Islamist movement, the Muslim Brotherhood (al-Ikhwān al-Muslimūn), founded by Ḥasan al-Bannā (1906-1949) in 1928, also has a female wing that supports the agenda of the movement, including veiling and the main role of women being in the home. The Muslim Brotherhood is known as "the parent body and main inspiration for many Islamist organizations in Egypt and several other Arab countries" (Ayubi et al 2019). Women's mobility in the public arena was part of al-Bannā's concern, which can be found in his article published in 1940 entitled "Risālah al Mar'a al Muslima" (Tadros 2011: $90)$. He warns of the danger of women's mobility: "This fascistic mingling of sexes among us in schools, institutes ... all of this is foreign goods which have absolutely no relation to Islam and has had the worst effects in our social life" (quoted in Tadros 2011: 91). Al-Bannā argues, "the difference between man and woman in rights is attributable to their different natures and in accordance with the different roles assigned to each" (quoted in Tadros 2011: 91). Indeed, al-Bannā's view on different gender roles have been echoed by many Islamists. Mir-Hosseini, for example, uses the term 'neotraditionalist' or 'neofig $h$ ' to refer to a new gender discourse written mostly by men to oppose Western concepts of gender equality (2016: 68). They use the concepts of 'equity' and 'complementarity' to emphasise the human nature of men and women (2016: 69).

One of the most prominent women within the Muslim Brotherhood's circle was Zaynab al-Ghazālī (1917-2005). Al-Ghazālī initially joined Hudā Sha' rāwī's 
Egyptian Feminist Union until she became "disaffected" and decided to construct her own association for pious Muslim women (Cooke 1994: 2). Later, al-Ghazālī was known as a fierce opponent of feminist movements and a promoter of conservative understandings of Islam. At the age of eighteen, al-Ghazālì founded the Jamā'at al-Sayyidāt al-Muslimāt (Muslim Women's Association) (Hoffman 2019). Supporting the agenda of the Islamist movement, she "maintained that women should have important public roles as long as it was in the defense of Islam and traditional Islamic values" (Ayubi et al 2019). As the most powerful female figure within the Egyptian Muslim Brotherhood, al-Ghazālī also experienced imprisonment. She shared her experiences in her memoir written in 1977 (Al-Ghazali 1994).

The Muslim Brotherhood spread through the Arab world, opposing the female vote and coeducation in the 1940s and 1950s (Tadros 2011: 92). Later, however, they proposed a reform of the status of women, maintaining their emphasis that women's domestic responsibilities should be centre stage. Their position that women's domestic responsibilities are their 'noble tasks' and 'noble missions' has been maintained. The Muslim Brotherhood's election platform of 2006, states that, "We must not forget that the woman has a noble and significant task entrusted to her by Allah Almighty, child bearing and motherhood ... these duties must be given precedence over other responsibilities ... However, the husband has a right to permit his wife to work" (quoted in Tadros 2011: 92). Permission from one's husband has become the main gate for a woman to become active in public, outside of the home.

\subsection{Beyond the Muslim Brotherhood}

Following women within the Muslim Brotherhood's circle, this kind of Islamist movement has attracted a large number of young women, especially since the 1970s. One of their main role models has been al-Ghazālī. Valerie Hoffman contends, "Zaynab al-Ghazali stands out thus far as the only woman to distinguish herself as one of its major leaders" (Hoffman 2019). During the last quarter of the twentieth century, many Muslim-majority countries started to witness the rise of Islamist movements along with a broader resurgence of piety. This phenomenon also attracted many women to Islamist movements, such as those in Indonesia, Iran, Egypt, Turkey, Palestine, Pakistan, Jordan, and Yemen.

Many Islamist movements have been inspired by the Muslim Brotherhood, including Jamāat-I Islāmī (The Islamic Party) which shares the Brotherhood's ideology (Ayubi et al 2019). Jamāat-I Islāmī, one of the oldest transnational Islamist movements, was founded in Lahore in 1941 by Islamist thinker and activist, Mawlānā Sayyid Abū al-Alā Mawdūdī. Its wide appeal can be seen among Muslim men and women not only in South Asia, but also in East Asia 
and the Middle East, North America, the UK, and other parts of Europe (Jamal 20og: 10). Sharing the Muslim Brotherhood's ideology in many aspects pertaining to women, Mawdūdī, like al-Bannā, also ruled that women have to veil themselves because women's body is a source of fitna, entry to the public domain can cause immorality, and he was against women's political roles (Ahmad 2008: 549). He was also against women becoming rulers, and quoted a hadith, "A nation which handed over its affairs [of state] to a woman would never prosper" (Ahmad 2008: 557). Similarly to the Muslim Brotherhood, Jamā'at-I Islāmì has also experienced some reforms pertaining to the status of women, especially from the 1970s onwards (Ahmad 2008: 549). Differing to the founder, the later generation believed that women should be allowed to leave their homes. In the early twentieth century, Muslim women began to be seen in modern politics and Jamā'at-I Islāmī started allowing female membership (Ahmad 2008: 558). The women's wing of Jamāat-I Islāmī was developed in the 195os. Similar to other Islamist women, they emphasise a return to Islam as the answer to moral decadence due to the infiltration of Western culture (Jamal 2009: 11). It is noteworthy that they are not anti-modernity (Jamal 2009: 12).

Another transnational Islamist movement, Hizb ut-Tahrir (Party of Liberation), was founded in Jerusalem in 1953 by Taqī al-Dīn al-Nabhānī (19o91977). With a main agenda to establish a global caliphate with non-violent methods. Women within Hizb ut-Tahrir are active in voicing their concerns pertaining to women and family issues. They are also active in using diverse media, including social media, to voice their concerns. Orofino, in her work on Muslimah Hizb ut-Tahrir in Australia, argues that the women are very active in this movement which has successfully appealed to young girls and has continuously contributed to the movement's agenda (2018: 277). Muslimah Hizb ut-Tahrir Indonesia, the women's division of the Indonesian chapter of Hizb ut-Tahrir, which was banned in 2017, also emphasises the vital role of women in preparing a pious young Muslim generation so that the khairu umma (the best Muslim community) can be realised (Nisa 2014a: 145).

Lately, many scholars have focused their attention on elucidating why women's participation in Islamist movements and their parties have increased through time. Indeed, the transformation of diverse Islamist movements in adopting a more pragmatic approach, which might be seen as sacrificing their core ideological commitments for political gain, has created supportive environments for encouraging the presence of women. The literature on the inclusion-moderation hypothesis in analysing the strategies of some Islamist parties and their political actors signifies a tendency to be more inclusive and suggests their democratic commitment as a response to political opportunities 
(see Bayat 2013; Tezcur 2010; Hasan 2013), including issues pertaining to the position of women in politics.

Today, women within Islamist parties have more influence. They are present within the ranks of political parties which adopt Islamist ideology (see Clark and Schwedler 2003; Arat 2005 on women within an Islamist Refah party in Turkey; Rinaldo 2013 on women within an Indonesian Islamist party, the Prosperous Justice Party). Clark and Schwedler, for example, focusing their work on women's activists in Islamist groups in Jordan, Jabhat al-Amal al-Islāmī (Islamic Action Front, or IAF) and Yemen, Tajammu' al-Yamanī li al-Ișlāh (Yemeni Reform Group), argue that in 1989 and 1990 these two largest Islamist groups expressed a strong opposition to the full and equal political participation of women, however, a decade later they demonstrated that the parties have women in their highest decision making bodies (Clark and Schwedler 2003: 308-9).

\subsection{Tablìghījamā'at}

Besides the involvement of women and political Islam, women have also been the backbone of other Islamic resurgence movements, which are often considered apolitical or movements which strive to stay away from political controversies (see also Sikand 2006). Tablīghī Jamā'at is an example of this current. Tablīghī Jamā'at was founded in 1926 in Mewat by Mawlānā Muḥammad Ilyās (1885-1944).

Tablīghī Jamāat's views of women is similar to those of other conservative movements, especially Salafism. Although women are active in diverse Tablīghì activities, they have to observe a specific standard of morality, such covering their bodies properly during Tablīghī activities by donning a face-veil. This includes the main core activity of Tablīghì Jamā'at, khurūj (going out of one's own neighbourhood to proselytise) (Nisa 2014b: 470; see also Metcalf 1998, 2009). Mirroring views of 'ulamä' (Muslim clerics) within Islamist movements, Tablīghī 'ulamā' initially did not approve women's khurūj "arguing that this was 'an age of great disorder' with women going out of their homes without covering themselves 'properly', and that tabligh tours might actually be used by women as an 'excuse' for 'turning towards freedom'" (Sikand 1999: 43). However, Ilyās' continuous effort to seek approval from Tablīghī Jamā'at's elites to allow women to participate in Tablīghī work finally received a positive response, and nowadays, Tablīghī women are as active as their male counterparts. They participate in khurüj as long as they are accompanied by their mahram, especially their husband or other close male kin from their immediate family (Nisa 2014b: 482).

My work on Tablīghī Jamā'at in Indonesia, which can be regarded as one of the biggest branches of this movement, demonstrates the appeal of this 
movement not only to Muslims from underserved communities, but also urban middle and high-class wealthy women (Nisa 2011: 135) and school aged girls who are willing to learn the basic teachings of Tablīghi Jamā'at through the growing presence of Tablīghì Islamic boarding schools (Nisa 2014b: 468). The involvement of women of privileged backgrounds questions the common stereotype of Tablīghī Jamāatat women, who are commonly seen as women strictly wearing face-veils, hence they are often portrayed as oppressed women. Indeed, the involvement of these women from privileged social backgrounds signifies that "their passion to return to the true path of Islam and the commitments it embodies have made them aware of their capacity to exercise agency within the movement's structuring conditions" (Amrullah 2011: 135). They have been active in recruiting and sustaining the movement, especially women's Tablīghī networks.

\section{7}

\section{Conclusion}

This chapter does not aim to be exhaustive and cover all issues pertaining to women and Islamic movements. The chapter begins with a historical overview of the position of important female figures in Islam, especially those of the Prophet Muhammad's circle, who later became the main inspiration for women in diverse movements ranging from Islamic to Islamist movements. One important point in the discussion of women and their activism, including their attachment to diverse Islamic and Islamist movements, is how they frame their attachment in the name of religious language. Both Islamic feminists and conservative women, for example, return to the Qur'ān and position women within the Prophet Muhammad's circle as their sources of inspiration to justify their activism. In this context, Abu Zayd's remark resonates with the phenomenon in which he said, "the Quran is at the mercy of the ideology of its interpreter. For a communist, the Quran would thus reveal communism, for a fundamentalist it would be a highly fundamentalist text, for a feminist it would be a feminist text, and so on" (2006: 91). The wide spectrum of the position of women and their activism reminds us not only of their diverse opinions, but also that different contexts can lead to different expressions of Muslim activism. Therefore, in studying Muslim women, there is no such thing as a global context. This chapter demonstrates how some Islamist women support gender hierarchy, while at the same time, Islamic feminists and progressive Muslim thinkers strive to fight against gender hierarchy.

Any discussions pertaining to women cannot neglect the position of men. Deeply rooted patriarchal understandings of religious texts have been prevalent in diverse religious traditions, including Islam. On the other hand, 
throughout the history of Muslim women's activism, we can see that women have worked in collaboration with modernist male Muslims toward emancipation and gender justice. Similar to women within the circles of Islamic feminism and those who belong to diverse Islamic movements that support gender just interpretations of the Quraan and other religious texts, women who have become active in women's wings within Salafist and diverse Islamist movements, also produce or echo their male counterparts' readings and rereadings of the Qur'ān and other religious texts. While women within diverse Islamic movements, including those of Islamic feminist movements, emphasise gender equality and egalitarian gender roles, Islamist and other conservative women strengthen the concepts of equity and complementarity. The growing presence of women within diverse Islamist movements and their Islamist parties, from Southeast Asia to the Middle East, demonstrate the vital position of women. The moderation of Islamist parties due to their intention to achieve political gain has led to the presence of a positive political atmosphere for Islamist women. Women in diverse Islamist parties have become important strategic and potential agents to gain political gain and enjoy diverse political incentives.

This chapter suggests that anyone who wants to understand Muslim women and their activism within diverse Islamic and Islamist movements must avoid the inclination to make broad and unqualified generalisations. The wide geographical scope covered in this chapter also reminds us of the diversity within Muslim-majority countries. A continuous ideological tension can be seen from one movement or organisation. In addition, women's backgrounds need to be considered when reading their activities, because women from underserved communities might be different from those of more privileged backgrounds. Therefore, it is important to underline the specific socio-cultural economic, and political contexts and orientations of women's activism. Any activism should be understood within contextualised and localised settings with their own dynamics and specifics.

\section{References}

Abbas, S.B. 2002. The Female Voice in Sufi Ritual: Devotional Practices in Pakistan and India. Austin: University of Texas Press.

Abbot, N. 1942. Aishah, the Beloved of Mohammad. Chicago: University of Chicago Press.

Abboud, H. 2014. Mary in the Qur'ān: A Literary Reading. London and New York: Routledge. 
Abu Zayd, N. 2006. Reformation of Islamic Thought. Amsterdam: Amsterdam University Press.

Ahmad, I. 2008. "Cracks in the 'Mightiest Fortress': Jamaat-e-Islami's Changing Discourse on Women." Modern Asian Studies. 42:2/3, 549-575.

Ahmed, L. 1984. "Early Feminist Movements in the Middle East: Turkey and Egypt." In F. Hussain ed., Muslim Women. New York: St. Martin's Press, 111-123.

Ahmed, L. 1992. Women and Gender in Islam: Historical Roots of a Modern Debate. Michigan, London: Yale University Press.

Al-Bukhārī, M. n.d. Șaḥị̣ al-Bukhārī. Sunnah.com. At https://sunnah.com/bukhari. Accessed 11/06/2020.

Al-Ghazali, Z. 1994. Return of the Pharaoh: Memoir in Nasir's Prison. Trans. M. Guezzou. Leicester: Islamic Foundation.

Amrullah, E.F. 2011. "Seeking Sanctuary in 'the Age of Disorder': Women in Contemporary Tablīghī Jamā'at." Contemporary Islam. 5:2, 135-16o.

Andaya, B.W. 20o6. The Flaming Womb:Repositioning Women in Early Modern Southeast Asia. Honolulu: University of Hawaii Press.

Arat, Y. 2005. Rethinking Islam and Liberal Democracy: Islamic Women in Turkish Politics. NY: State University of New York Press.

Arnez, M. 2010. "Empowering Women Through Islam: Fatayat NU Between Tradition and Change." Journal of Islamic Studies. 21:1, 59-88.

Ayubi, N.N., J.A. Kéchichian, D.J. Sullivan, J.A. Kéchichian, F.H. Lawson, and M. Boulby, 2019. "Muslim Brotherhood." In The Oxford Encyclopedia of the Islamic World. Oxford Islamic Studies Online. At http://www.oxfordislamicstudies.com/article/opr/t236/ eo566. Accessed 19/04/2019.

Badran, M. 1995. Feminists, Islam, and Nation: Gender and the Making of Modern Egypt. Princeton: Princeton University Press.

Badran, M. 2001. "Understanding Islam, Islamism, and Islamic Feminism." Journal of Women's History. 13:1, 47-52.

Badran, M. 2002. "Islamic Feminism: What's in a Name?" Al-Ahram Weekly. At http:// weekly.ahram.org.eg/2002/569/cu1.htm. Accessed 23/04/2019.

Badran, M. 2005. "Between Secular and Islamic Feminism/s: Reflections on the Middle East and Beyond." Journal of Middle East Women's Studies. 1:1, 6-28.

Badran, M. 2019. "Feminism." The Oxford Encyclopedia of the Islamic World. Oxford Islamic Studies Online. At http://www.oxfordislamicstudies.com/article/opr/t236/ eo246. Accessed 14/04/2019.

Barlas, A. 2002. Believing Women in Islam: Unreading Patriarchal Interpretations of the Qur'ān. Austin: University of Texas Press.

Barlas, A. 2008. "Engaging Islamic Feminism: Provincializing Feminism as a master narrative." In A. Kynsilehto ed., Islamic Feminism: Current Perspectives. Finland: University of Tampere, $15^{-24}$. 
Basarudin, A. 2016. Humanizing the Sacred: Sisters in Islam and the Struggle for Gender Justice in Malaysia. Seattle and London: University of Washington Press.

Bauer, K. 2015. Gender Hierarchy in the Qur'ān: Medieval Interpretations, Modern Responses. Cambridge, UK: Cambridge University Press.

Bayat, A. 2013. "Post-Islamism at large." In A. Bayat ed., Post-Islamism: The Changing Faces of Political Islam. Oxford/New York: Oxford University Press, 3-34.

Bint al-Shati' [A'isha Abd al-Rahman]. 1961. Nisa' al-Nabi, Umm al-Nabi, Batala Karbala': Zaynab bint al-zahra'. Beirut: Dar al-Kitab al-Arabi.

Blaydes, L. and S. El Tarouty. 20o9. "Women's Electoral Participation in Egypt: The Implications of Gender for Voter Recruitment and Mobilization." The Middle East Journal. 63:3, 364-380.

Brijbhushan, J. 1990. Sultan Raziya, Her Life and Times: A Reappraisal. New Delhi: Manohar.

Brown, J.A.C. 2014. Misquoting Muhammad: The Challenge and Choices of Interpreting the Prophet's Legacy. London: Oneworld.

Bush, R. 2009. Nahdlatul Ulama and the Struggle for Power within Islam and Politics in Indonesia. Singapore: ISEAS.

Charrad, M.M. 2011. "Gender in the Middle East: Islam, State, Agency." The Annual Review of Sociology. 37, 417-37.

Clark, J.A. and J. Schwedler. 2003. “Who Opened the Window? Women's Activism in Islamist Parties." Comparative Politics. 35:3, 293-312.

Clavé, E. 2020. "Heroines and Forgotten Fighters: Insights into Women Combatants' History in Aceh, 1873-2005." In V. A. Lanzona, and F. Rettig eds, Women Warriors in Southeast Asia. Oxon and New York: Routledge, 109-135.

Cooke, M. 1994. “Zaynab al-Ghazālī: Saint or Subversive?" Die Welt des Islams. 34:1, 1-20.

Deeb, L. 2006. "Lebanese Shia Women Temporality and Piety." ISIM. 18:1, 32-33.

El Saadawi, N. 1997. The Nawal El Saadawi Reader. London and New York: Zed Books.

Fazaeli, R. 2017. Islamic Feminisms: Rights and Interpretations across Generations in Iran. Oxon, New York: Routledge.

Geissinger, A. 2015. Gender and Muslim Constructions of Exegetical Authority: A Rereading of the Classical Genre of Qur'ān Commentary. Leiden: Brill.

Hasan, N. 2013. "Post-Islamist Politics in Indonesia." In A. Bayat ed., Post-Islamism: The Changing Faces of Political Islam. Oxford, New York: Oxford University Press, 157-184.

Hoffman, V.J. 2019. "Ghazālī, Zaynab al-." In The Oxford Encyclopedia of the Islamic World. Oxford Islamic Studies Online. At http://www.oxfordislamicstudies.com/ article/opr/t236/eo273. Accessed 16/o4/2019.

Inge, A. 2016. The Making of a Salafi Muslim Woman: Paths to Conversion. New York: Oxford University Press. 
Jamal, A. 2009. "Gendered Islam and Modernity in the Nation-Space: Women's Modernism in the Jamaat-e-Islami of Pakistan." Feminist Review. 91, 9-18.

Jones, S. 2008. The Jewel of Medina: A Novel. New York: Beaufort Books.

Kolman, I. 2017. "Gender Activism in Salafism: A Case Study of Salafi Women in Tunis." In F. Cavatorta and F. Merone eds, Salafism after the Arab Awakening: Contending with People's Power. Oxford \& New York: Oxford University Press, 188-215.

Koning, M. de 20o9. "Changing Worldviews and Friendship: An Exploration of the Life Stories of Two Female Salafis in the Netherlands." In R. Meijer ed., Global Salafism: Islam's New Religious Movement. New York: Columbia University Press, 404-423.

Krämer, G. and S. Schmitdke. 20o6. "Introduction: Religious Authority and Religious Authorities in Muslim Societies: A Critical Overview." In G. Krämer and S. Schmidtke eds, Speaking for Islam: Religious Authorities in Muslim Societies. Leiden: Brill, 1-14.

Krokus, M. and R. Catharina. 2020. "Sufism and Women." In The Oxford Encyclopedia of Islam and Women. Oxford Islamic Studies Online. At http://www.oxfordislamic studies.com/article/opr/t355/eoo34. Accessed o9/o6/2020.

Künkler, M. and E.F. Nisa. 2018. "Re-establishing Juristic Expertise: A Historic Congress of Female Islamic Scholars." International Institute for Asian Studies. 79:7.

Lal, R. 2005. Domesticity and Power in the Early Mughal World. Cambridge, UK: Cambridge University Press.

Larsson, G. 2015. "Hadīth al-ifk in one Contemporary Western Novel." In S. Olofsson ed. Den Trogne Arbetaren I Vingården: Festskrift till Bo Claesson. Gothenburg: Göteborgs Universitet, 101-108.

Meijer, R. 20o9. "Introduction." In R. Meijer ed., Global Salafism: Islam's New Religious Movement. New York: Columbia University Press, $1-32$.

Mernissi, F. 1987. Beyond the Veil: Male-Female Dynamics in Modern Muslim Society. Bloomington and Indianapolis: Indiana University Press.

Mernissi, F. 1993. The Forgotten Queens of Islam. Minneapolis: University of Minnesota Press.

Mernissi, F. 1998. “A Feminist Interpretation of Women's Rights in Islam.” In C. Kurzman ed., Liberal Islam: A Sourcebook. New York, Oxford: Oxford University Press, 112-126.

Metcalf, B.D. 1998. "Women and Men in a Contemporary Pietist Movement: The Case of Tablighi Jama'at." In A. Basu and P. Jeffery eds, Appropriating Gender: Women's Activism and Politicized Religion in South Asia. New York: Routledge, 107-121.

Mir-Hosseini, Z. 2006. “Muslim Women's Quest for Equality: Between Islamic Law and Feminism." Critical Inquiry. 32, 629-645.

Mir-Hosseini, Z. 2016. "Moral Contestations and Patriarchal Ethics: Women Challenging the Justice of Muslim Family Laws." In R.W. Hefner ed., Shari'a Law and Modern Muslim Ethics. Indiana: Indiana University Press, 65-83.

Moghissi, H. 1999. Feminism and Islamic Fundamentalism. London: Zed Books. 
Nadjib, A. 2020. "Fatayat Nahdlatul 'Ulamā'." In The Oxford Encyclopedia of Islam and Women. Oxford Islamic Studies Online. At http://www.oxfordislamicstudies.com/ article/opr/t355/eo118. Accessed o6/o6/2020.

Nisa, E.F. 2012. "Embodied Faith: Agency and Obedience among Face-veiled University Students in Indonesia." The Asia Pacific Journal of Anthropology. 13:4, 366-381.

Nisa, E.F. 2013. "The Internet Subculture of Indonesian Face-veiled Women." International Journal of Cultural Studies. 16:3, 241-255.

Nisa, E.F. 2014a. "The Marginalised Majority: Indonesian Muslim Women on Nationalism." RIMA: Review of Indonesian and Malaysian Affairs. 48:1, 127-158.

Nisa, E.F. 2014b. "Insights into the Lives of Indonesian Female Tablīghī Jamā'at." Modern Asian Studies. 48:2, 468-491.

Nisa, E.F. 2019. "Muslim Women in Contemporary Indonesia: Online Conflicting Narratives behind the Women Ulama Congress." Asian Studies Review. 43:3, 434-454.

Orofino, E. 2018. "Longing for the Caliphate while Living in the State: An Agent-Structure Analysis of the Appeal of Hizb ut-Tahrir to Muslims in the West." Doctoral Dissertation. University of Melbourne, Australia.

Papanek, H. and Minault, G. 1982. Separate Worlds: Studies of Purdah in South Asia. Columbia, Mo.: South Asia Books.

Pemberton, K. 2006. "Women Pirs, Saintly Succession, and Spiritual Guidance in South Asian Sufism." Muslim World. 96, 61-87.

Reid, A. 1988. "Female Roles in Pre-Colonial Southeast Asia." Modern Asian Studies. 22:3, 629-645.

Rinaldo, R. 2013. Mobilizing Piety: Islam and Feminism in Indonesia. Oxford: Oxford University Press.

Robinson, K. 2008. Gender, Islam, and Democracy in Indonesia. London: Routledge.

Roded, R. 2006. "Bint al-Shati's Wives of the Prophet: Feminist or Feminine?" British Journal of Middle Eastern Studies. 33:1, 51-66.

Ruffle, K.G., K. Pemberton, and N. Isgandarova. 2020. "Gender Themes." The Oxford Encyclopedia of Islam and Women. Oxford Islamic Studies Online. At http://www .oxfordislamicstudies.com/article/opr/t355/eool1. Accessed o9/o6/2020.

Sayeed, A. 2015. Women and the Transmission of Religious Knowledge in Islam. New York: Cambridge University Press.

Schröter, S. 2017. "Islamic Feminism." In J. Cesari and J. Casanova eds, Islam, Gender and Democracy in Comparative Perspective. Oxford: Oxford University Press, 113-136.

Sikand, Y. 1999. "Women and the Tablighi Jama'at." Islam and Christian-Muslim Relations. 10:1, 41-52.

Sikand, Y. 2006. “Tablighi Jamā'at and Politics: A Critical Re-appraisal." The Muslim World. 96:1, 175-195.

Spellberg, D. 1991. "Political Action and Public Example: 'A'isha and the Battle of the Camel." In N.R. Keddie and B. Baron eds, Women in Middle Eastern History: Shifting Boundaries in Sex and Gender. New Haven, CT: Yale University Press, 45-57. 
Stowasser, B.F. 1997. Women in the Qur'ān, Traditions, and Interpretation. New York: Oxford University Press.

Syamsiyatun, S. 2007. "A Daughter in the Indonesian Muhammadiyah: Nasyiatul Aisyiyah Negotiates a New Status and Image." Journal of Islamic Studies. 18:1, 69-94. Tadros, M. 2011. “The Muslim Brotherhood's Gender Agenda: Reformed or Reframed?" ID S Bulletin. 42:1, 88-98.

Tezcur, G.M. 2010. The Paradox of Moderation: Muslim Reformers in Iran and Turkey. Austin: University of Texas Press.

Thurlkill, M.F. 2010. Chosen among Women: Mary and Fatima in Medieval Christianity and Shi'ite Islam. Indiana: Notre Dame Press.

Tønnessen, L. 2016. "Ansar al-Sunna and Women's Agency in Sudan: A Salafi Approach to Empowerment through Gender Segregation." A Journal of Women Studies. 37:3, 92-124.

Van Doorn-Harder, P. 2006. Women Shaping Islam: Reading the Qur'ān in Indonesia. Urbana: University of Illinois Press.

Wadud, A. 2006. Inside the Gender Jihad: Women's Reform in Islam. Oxford: Oneworld. Wiktorowicz, Q. 2006. "Anatomy of the Salafi movement." Studies in Conflict \& Terrorism. 29:3, 207-39.

Winter, B. 2001. "Fundamental Misunderstandings: Issues in Feminist Approaches to Islamism." Journal of Women's History. 13:1, 9-41.

Yousef, H. 2011. "Malak Hifni Nasif: Negotiations of a Feminist Agenda between the European and the Colonial." Journal of Middle East Women's Studies. 7:1, 70-89. 